American Journal of Agricultural and Biological Sciences 5 (3): 350-356, 2010

ISSN 1557-4989

(C) 2010 Science Publications

\title{
Acceptance and Sustainability of Contract Farming Among Youth in Malaysia
}

\author{
Jeffrey Lawrence D’Silva, Hayrol Azril Mohamed Shaffril, \\ Jegak Uli and Bahaman Abu Samah \\ Laboratory of Rural Advancement and Agricultural Extension, \\ Institute for Social Science Studies, University Putra Malaysia, Malaysia
}

\begin{abstract}
Problem statement: Contract farming is one of the agriculture branches that is ready to be discovered for its huge potential and it is perceived as a new dimension which offers agricultural sustainability. But do the youth as the pillar of this sector do accept agriculture? Thus, this study would like to discover factors that affect acceptance of youth towards contract farming in Malaysia. Approach: This is a quantitative study using a survey form. Data was gathered from 400 undergraduates studying in various tertiary institutions and were analyzed using the PASW software. The data collection process took two months to be completed. Results: Results depict that the respondents studied have a high and positive acceptance towards contract farming. Based on the analysis performed, factors of attitude, knowledge and belief are significant predictors of acceptance towards contract farming. Conclusion/Recommendations: It is believed that the findings of this study would add new perspective on understanding the complexities associated with agricultural sustainability among youth. Results gained provide a sign for policy makers to utilize education as a tool to increase youths' positive attitude towards farming. Based on the results it is recommended that more specific courses related to contract farming can be exposed at the tertiary level in order to enhance youth's awareness and acceptance towards contract farming. Eventually, this would set the direction into getting more youth to be involved in innovative farming activities and in the end it would make agriculture to be attractive and maintain its sustainability.
\end{abstract}

Key words: Contract farming, sustainability, youth, acceptance, Malaysia

\section{INTODUCTION}

Unsurprisingly without any qualms the agriculture sector remains as one of the pertinent sectors in many countries and its invaluable contribution in enhancing the economy of a nation cannot be disputed. However, making it sustainable continuous to be an immense challenge due to the insurmountable challenges that threaten farming sustainability (Amekawa et al., 2010).

In Malaysia the sustainability of the agriculture sector has not been neglected and in intensifying this industry, the government has implemented a variety of initiatives. For instance, in The Ninth Malaysian Blueprint, this sector has been channeled as the third impetus to boost the income of the country while recently in the 2010 budget, Malaysia has announced that almost USD 1.6 billion has been allotted to develop this sector and to further buttress the livelihoods of farmers. Besides, the establishment of a number of government agencies such as Department Of Agriculture (DOA), Malaysian Agriculture and
Development Research Institute (MARDI), Federal Agriculture Marketing Authority (FAMA), Farmers Organization Authority (FOA) and other agriculture agencies have further boosted the efforts of the government to develop this sector.

One of the modern agriculture methods that can be undertaken to ensure sustainability of the agricultural sector is to embark on contract farming and lately it has been advocated by policy makers, development planners, extension agents and researchers as an important tool to overcome the malaise faced by the agriculture sector. There are a variety of contract farming activities such as rearing of leeches, goats and cows, bird nest, herbs and others that offer a huge potential to those who are interested to run it. According to Da Silva (2005), even though contract farming is not a novel issue, the development in the topic of contract farming has reached a significant level caused by changes and trends that affect agro-systems worldwide. Recently, consumptions habits of Malaysia has been affected by the rise of fast food outlets either

Corresponding Author: Jeffrey Lawrence D’Silva, Laboratory of Rural Advancement and Agricultural Extension, Institute for Social Science Studies, University Putra Malaysia, Malaysia 
local or international, the emergence of giant hypermarkets and wider opportunities for international trade in fresh and processed products. All of these have swayed the need for contract farming development in Malaysia.

Recognizing the existence of aging farmers in the agriculture community that would put additional pressure towards farming sustainability, it is significant to reinforce the participation of the younger generation especially the youth in farming. Studies done by Hassan and Azril (2009) and Ezhar et al. (2007) proved that the average age of farmers in Malaysia exceeds 46 years old while according to Norsida (2007), majority of farmers identified in her study were 55 years and above and only less than $26 \%$ of farmers were among those whose age ranged between 15-40 years. Hence, action must be taken to drive the interests of the youth towards agriculture. Agriculture indeed can be a catalyst that can overcome the unemployment problem. According to Man (2007), youth in Malaysia have a negative acceptance towards agriculture. However, a further study by Man (2008) noted that even though youth in Malaysia have negative acceptance towards agriculture, they still believed that agriculture is a profitable industry if it is accompanied with hard work and relentless efforts. New trends and ways to run the agriculture are required in order to attract the interests of youth and enhance their participation in agriculture. Contract farming is a fresh industry in Malaysia and have the ability to attract more youth to participate based on its method which is easy and profitable. In fact, contract farming as being experienced in a number of countries was able to provide alternative markets for small markets and guaranteed consistent supply to the markets especially in the field of medicine, health and raw meat products.

Contract farming and its different facets: A range of terms are used to describe contract farming but generally it can be defined as an agreement between farmers or primary producers and marketing or processing firms (in common known as the buyer) whereby the core of such arrangements being a pledge by the producers to provide an agricultural commodity of a type, at a specified time, price and in specified quantity to a known buyer (Singh, 2005). Morrison et al. (2006) further states that within the last 30 years, contract farming has become an increasingly characteristic organizational form in the global agrifood system, facilitating linkages between farmers and purchasers whereby in general the purchaser would support production in supplying the inputs, providing technical advice and purchasing the commodity and on the other hand the producers would provide a specific commodity in quantities and at quality standards determined by the purchaser.

The intensity of the contractual arrangement varies according to the depth and complexity of the transactions and according to Minot (1986) the format of a contract farming can be classified into three areas, namely 'market specification', 'resource providing' and 'production management'. In the first modality, the grower and buyer agree to terms and conditions for the future sales and purchase of a crop or livestock product. On the other hand, in the second modality, in conjunction with the marketing arrangements the buyer agrees to supply selected inputs, including on occasions land preparation and technical advice. Finally, under 'product management' contract growers agree to follow recommended production methods, input regimes and cultivation and harvesting specifications. However, regardless of the typology, Da Silva (2005) sees that in general the term 'contract farming' is viewed as a particular form of supply chain governance implemented by firms to secure access to agricultural products, raw materials and supplies meeting desired quality, quantity, location and timing specifications.

Besides, contract farming too has its various types based on the model being adopted among them are the centralized model, nucleus estate model, multipartite model, informal model and intermediary model. According to Mansur et al. (2009), the centralized model is a vertical coordination where the sponsor purchases the crop from farmers and processes and markets the products and quotas of farmers are normally distributed at the beginning of each growing season and quality is tightly controlled (Eaton, 2001). On the other hand, the second model as stated by Mansur et al. (2009) is the nucleus estate model whereby the sponsor of the project owns and manages an estate plantation which is often fairly large in order to provide some guarantee of throughput for the plant. On top of it, the third model, that is, the multipartite model usually involves many types of agencies, intermediary model where middlemen are involved between the company and the farmer. The fourth model, the informal model, according to Mansur et al. (2009) applies to individual entrepreneurs or small companies who normally make simple, informal production contracts with farmers on a seasonal basis, particularly for crops such as fruits. In the final model, that is the intermediary model, sees the presence of middlemen between the company and the farmer. However, Mansur et al. (2009) state that middlemen could pose a problem since subcontracting disconnects the direct link between the sponsor and producer. 
Factors affecting youth acceptance towards contract farming: The rise of existing literature, prove that there are abundance of factors that can be associated with acceptance of youth towards contract farming. Attitude is one of the identified factors. Usually positive attitude will drive to better acceptance and negative attitude will sway negative acceptance. This has been proved by a study done by Gidarakou (1999) who noted that majority of youth have negative attitude and this resulted in difficulties to accept contract farming. A study completed by Kumar (2007) opposes to what have been clarified by Gidarakou (1999) where he emphasized that what contract farming has got to offer to the community possess the ability to increase youth's acceptance of contract farming. Through his research, it can be noted that lately more farmers in India choose for contract farming due to positive attitude as a result of price protection on their crops. The study done by Kumar (2007) further strengthens the study done by Mann and Kogl (2003), where they emphasized that bigger profits garnered through contract farming will be an impetus for creating positive attitude of the people towards contract farming and perhaps this will boost their acceptance towards contract farming.

Knowledge can be a paramount determinant for contract farming acceptance among youth. A study completed by Shaban et al. (2006) stressed that acceptance is determined by the access to the related knowledge while according to James (2004), people refuse to accept what agriculture can offer including contract farming because of their lack of knowledge. Frick et al. (1995) noted that acceptance towards agriculture will increase if the literacy knowledge level among the citizen can be enhanced. Knowledge without doubt holds the main key in influencing perception and this trend is set to intensify. In the 21st century, knowledge accumulation and application will drive people's perception. Knowledge, which can be defined as organized or processed information or data, is fundamental in enhancing the understanding of someone towards something. The most important element to be practiced for the benefit of this new industry is to practice what have been disseminated and the production of knowledge is achieved by exposing what is known to what is not known. When this occurs, it increases the possibility of having more positive perception towards contract farming.

Support towards contract farming is essential in ensuring its success. A study done by Guo et al. (2005) noted that government support, contractor characteristics and product or enterprise type are the major determinants of people's acceptance towards contract farming. Government support is important in motivating youth to accept contract farming. Referring to a study done by Wheeler (2008), it was suggested that those who are interested in contract farming need more help to do so especially on information provision, specialist extension support, farm demonstration and policy support.

While knowledge, attitude and support seem to be major contributors towards acceptance of contract farming, belief also plays a significant role in enhancing youths' acceptance towards contract farming (Adrian et al., 2005). When people believe contract farming is beneficial to them, this indeed will increase their acceptance towards contract farming.

\section{MATERIALS AND METHODS}

A total of 400 university students were selected as the respondents for this study. The selected students represented four universities in Malaysia with the background of agriculture, economics and others. A pre-tested and developed questionnaire was used to gain the data needed. Self-administered method was employed in the data collection process. In order to achieve the objectives of this study, descriptive statistics such as frequency, percentage, mean and standard deviation were used while inferential statistics such as Pearson Correlation and Multiple Linear Regression were employed to determine factors that influence youths' acceptance towards contract farming. The dependent variable for this study is acceptance towards contract farming while there are five independent variables namely attitude, knowledge, belief, support and perception towards contract farming.

\section{RESULTS}

A large majority of the respondents in this study were females $(70.8 \%)$. This is consistent with the current situation in Malaysia where female students are the dominant group in the higher learning institutions. Findings from this study also noted that more than four fifth of the respondents $(90.0 \%)$ were Malay. A total of $40.2 \%$ of the respondents age between 20-21 years old with the mean age of 20.78 years old. Three quarter of the respondents $(75.0 \%)$ are taking degree courses. From the data presented in Table 1, it can be clarified that a total of $31.8 \%$ of the respondents spend between 300-400 Ringgit Malaysia a month with the mean score of 395.85, half of them are taking agriculture courses $(50.0 \%)$, majority of them live in urban area $(59.5 \%)$, slightly more than three quarter of the respondents' family have agriculture background while more than half of the respondents $(54.8 \%)$ have received information concerning contract farming (Table 1). 
Am. J. Agri. \& Biol. Sci., 5 (3): 350-356, 2010

Table 1: Socio-demographic of respondents

\begin{tabular}{|c|c|c|c|c|}
\hline Variables & Frequency & Percentage & Mean & SD \\
\hline \multicolumn{5}{|l|}{ Gender } \\
\hline Male & 117 & 29.2 & & \\
\hline Female & 283 & 70.8 & & \\
\hline \multicolumn{5}{|l|}{ Ethnic } \\
\hline Malay & 360 & 90.0 & & \\
\hline Chinese & 15 & 3.8 & & \\
\hline Indian & 14 & 3.5 & & \\
\hline Others & 11 & 2.7 & & \\
\hline Age & & & 20.78 & 1.53 \\
\hline $18-19$ years & 111 & 27.8 & & \\
\hline $20-21$ years & 161 & 40.2 & & \\
\hline $22-24$ years & 128 & 32.0 & & \\
\hline \multicolumn{5}{|l|}{ Zone (the university located) } \\
\hline Northern & 100 & 25.0 & & \\
\hline Central & 100 & 25.0 & & \\
\hline East Coast & 100 & 25.0 & & \\
\hline Southern & 100 & 25.0 & & \\
\hline \multicolumn{5}{|l|}{ Level of recent education received } \\
\hline Degree & 300 & & & \\
\hline Diploma & 100 & & & \\
\hline Monthly expenditure (value in ringgit Malaysia) & & & 395.85 & 217.18 \\
\hline$<200$ & 57 & 14.2 & & \\
\hline 201-300 & 102 & 25.5 & & \\
\hline $301-400$ & 127 & 31.8 & & \\
\hline$>401$ & 114 & 21.5 & & \\
\hline \multicolumn{5}{|l|}{ Courses taken } \\
\hline Agriculture & 200 & 50.0 & & \\
\hline Economic & 100 & 25.0 & & \\
\hline Others & 100 & 25.0 & & \\
\hline \multicolumn{5}{|l|}{ Locality } \\
\hline Rural & 162 & 40.5 & & \\
\hline Urban & 238 & 59.5 & & \\
\hline \multicolumn{5}{|l|}{ Family background $(\mathrm{n}=381)$} \\
\hline Have agriculture background & 79 & 19.8 & & \\
\hline Do not have agriculture background & 302 & 75.5 & & \\
\hline \multicolumn{5}{|l|}{ Received information regarding contract farming } \\
\hline Yes & 219 & 45.2 & & \\
\hline No & 181 & 54.8 & & \\
\hline
\end{tabular}

Table 2: Overall level of acceptance towards contract farming

\begin{tabular}{lccll}
\hline Factors & Frequency & Percentage & Mean & SD \\
\hline Acceptance & & & 7.29 & 1.15 \\
Low (1.0-3.33) & 0 & 0.0 & & \\
Moderate (3.34-6.67) & 113 & 28.2 & & \\
High (6.68-10.0) & 287 & 71.8 & & \\
\hline
\end{tabular}

Next, the focus is into the respondents acceptance toward contract farming. As presented in Table 2, a large majority of respondents $(71.8 \%)$ have a high positive acceptance towards contract farming. A total of $28.2 \%$ of the respondents moderately accept contract farming. It is interesting to know that none of the respondents have a low level of acceptance towards contract farming. This is a good indicator for the future of agriculture in our country as the respondents believe that innovative agricultural methods will prompt them to embark in agriculture activities.

Table 3 indicates the four factors that affect acceptance and they were belief, knowledge, support and attitude. This study reveals that knowledge is not the main aspect that recorded the highest mean score.

Table 3: Factors affecting acceptance towards contract farming

\begin{tabular}{lrcll}
\multicolumn{1}{c}{$(\mathrm{n}=400)$} & & & & \\
\hline Factors & Frequency & Percentage & Mean & SD \\
\hline Belief & & & 7.67 & 1.25 \\
Low (1.0-3.33) & 0 & 0.0 & & \\
Moderate (3.34-6.67) & 76 & 19.0 & & \\
High (6.68- 10.0) & 324 & 81.0 & & \\
Knowledge & 2 & 0.5 & 7.54 & 1.25 \\
Low (1.0-3.33) & 105 & 26.2 & & \\
Moderate (3.34-6.67) & 293 & 73.3 & & \\
High (6.68- 10.0) & & & 7.53 & 1.31 \\
Support & 1 & .2 & & \\
Low (1.0-3.33) & 93 & 23.2 & & \\
Moderate (3.34-6.67) & 306 & 76.6 & & \\
High (6.68-10.0) & & & 7.33 & 1.38 \\
Attitude & 3 & 0.8 & & \\
Low (1.0-3.33) & 119 & 29.8 & & \\
Moderate (3.34-6.67) & 278 & 69.4 & & \\
High (6.68- 10.0) & & & &
\end{tabular}

On the other hand, the highest mean score was recorded by the aspects related to belief $(M=7.67)$. The second highest mean score was recorded by knowledge aspects $(\mathrm{M}=7.54)$, followed by support $(\mathrm{M}=7.53)$. The lowest mean score was recorded by attitude aspects $(M=7.33)$. 
Am. J. Agri. \& Biol. Sci., 5 (3): 350-356, 2010

Table 4: Relationship between independent variables and acceptance towards contract farming

\begin{tabular}{lll}
\hline Variables & $\mathrm{r}$ & $\mathrm{p}$ \\
\hline Attitude & 0.667 & 0.0001 \\
Knowledge & 0.621 & 0.0001 \\
Support & 0.583 & 0.0001 \\
Belief & 0.524 & 0.0001 \\
\hline
\end{tabular}

Table 5: Factors that contribute to acceptance towards contract farming using multiple linear regression

\begin{tabular}{llll}
\hline Independent variables & Beta & $\mathrm{t}$ & $\mathrm{p}$ \\
\hline Constant & & 5.823 & 0.0001 \\
Attitude & 0.388 & 8.220 & 0.0001 \\
Knowledge & 0.229 & 4.423 & 0.0001 \\
Belief & 0.159 & 3.519 & 0.0001 \\
\hline
\end{tabular}

One of the focal point of this study is to inspect any relationship that occur between acceptance towards contract farming and selected independent variables. To achieve this, Pearson product-moment correlation was employed. Data shown in Table 4 indicates that all the four independent variables which are attitude $(\mathrm{p}=0.0001)$, knowledge $(\mathrm{p}=0.0001)$, support $(\mathrm{p}=0.0001)$ and belief $(\mathrm{p}=0.0001)$ have significant and positive relationship with attitude towards contract farming. Based on the data gained, there is moderate relationship between attitude and acceptance towards contract farming $(r=0.667)$, knowledge and acceptance towards contract farming $(\mathrm{r}=0.621)$, support and acceptance towards contract farming $(r=0.583)$ and belief and acceptance towards contract farming $(\mathrm{r}=0.524)$.

To further analyze the data, multiple linear regression was employed for the purpose of revealing the significant contributors among the predictor variables in explaining acceptance towards contract farming. Based on the results of the multiple linear regression performed as in Table 5, it was identified that three independent variables gave the best prediction for acceptance towards contract farming and explained about $53 \%$ of variation in acceptance towards contract farming. These three variables are attitude, belief and knowledge.

\section{DISCUSSION}

From the results, it is noted that respondents who have better attitude towards contract farming will have better acceptance towards contract farming. The results here are consistent with a number of past studies that emphasized on relationship between attitude and acceptance. Stobbelaar et al. (2007) and Hyttia and Kola (2006) have proved that attitude will bring changes on people acceptance towards contract farming. Usually positive attitude towards something will drive people to accept new ideas.
Data presented in Table 5 also showed that there is significant and moderate relationship between knowledge and acceptance towards contract farming, youth with higher level of knowledge on contract farming is predicted to have a better acceptance towards contract farming. Knowledge cannot be denied its importance in creating positive acceptance towards contract farming. Knowledge holds the main key to everything, it can be a catalyst of development to anybody that posses it. Begum (2005) through his study noted that possession of technical knowledge will play a major role in driving someone to accept contract farming.

A significant and moderate relationship also occurred between belief and acceptance towards contract farming. Based on the results gained, it is deduced that youth with a positive belief towards contract farming will create a better level of acceptance towards contract farming. Duncan et al. (2004) noted that belief will play a significant role in intensifying acceptance and knowledge of youth regarding agriculture. The more youth belief that agriculture will generate profits, a better level of acceptance they will have. On top of it, Osborne and Dyer (2000) have similar view where they stressed that positive belief will result in positive attitude towards agriculture and will drive youth to accept agriculture.

\section{CONCLUSION}

Agricultural sustainability relies to a certain extent the involvement of youth as a catalyst to boost novel farming methods such as contract farming. The study was able to identify significant factors that would predict acceptance towards contract farming and the major ones are attitude, knowledge and belief. Youths need to possess a positive attitude so that they would foster their participation in agricultural activities and have positive mind-sets that would encourage them to be inclined towards farming. On top of it, youth too perceive knowledge and beliefs as integral for them to participate in farming activities. Hence, the results display a useful information for policy makers to utilize education as a tool to increase youths' positive attitude towards farming. It is recommended through the findings of this study that more specific courses pertaining to contract farming should be introduce at the tertiary level as this would lead to an increase in awareness and acceptance. Eventually, this would set the direction into getting more youth to be involved in innovate farming activities and in end it would make agriculture to be attractive and maintain its sustainability. 


\section{REFERENCES}

Adrian, A.M., S.H. Norwood and P.L. Mask, 2005. Producer's perception and attitudes towards precision agriculture technologies. J. Comput. Technol. Agric., 48: 256-271. DOI:10.1016/j.compag.2005.04.004

Amekawa, Y., H. Sseguya, S. Onzere and I. Carranza, 2010. Delineating the multifunctional role of agroecological practices: Toward sustainable livelihoods for smallholder farmers in developing countries. J. Sustain. Agric., 34: 202-228. DOI: 10.1080/10440040903433079

Begum, I.A., 2005. Vertically integrated contract and independent poultry farming systems in Bangladesh: A profitability analysis. J. Livestock Res. Rural Dev. http://www.lrrd.org/lrrd17/8/ara17089.htm

Da Silva, C.A.B., 2005. The growing role of contract farming in agrifood systems development; drivers, theory and practice. http://www.fao.org/ag/ags/subjects/en/agmarket/co ntractfarming.html

Duncan, D.W., T.W. Broyles and V. Tech, 2004. An evaluation of student knowledge and perception towards agriculture before and after attending a govenor's school for agriculture. J. Southern Agric. Educ. Res., 54: 280-292.

Eaton, C., 2001. Contract Farming: Partnerships for Growth. 1st Edn., Food and Agriculture Organization of the UN, Rome, ISBN: 10: 9251045933, pp: 176.

Ezhar, T., M.S. Rahim, M. Zainal Abidin, H. Mohamed Rezal and Y. Zamre, 2007. Micro agro-based entrepreneurs readiness in facing agriculture challenges. IPSAS Monograph Series Bil. 1/2007, University Putra Malaysia Publisher, Serdang, Malaysia, ISBN: 978-983-43110-1-8, pp: 7.

Frick, M.J., R.J. Birkenholz, H. Gardrner and K. Machtmes, 1995. Rural and urban inner-city high school student knowledge and perception of agriculture. J. Agric. Educ., 36: 1-9.

Gidarakou, I., 1999. Young women's attitude towards agriculture and women new roles in the Greek countryside: A first approach. J. Rural Stud., 15: 147-158. DOI: 10.1016/S0743-0167(98)00054-0

Guo, H., R.W. Jolly and J. Zhu, 2005. Contract farming in China: Supply chain or ball chain? Proceedings of the Minnesota International Economic Development Conference, Apr. 29-30, University of Minessota, Minessota, pp: 1-1.

Hassan, M.S., and M.S.H. Azril, 2009. Internet usage among agro-based entrepreneurs: Can it affect productivity. J. Agric. Exten. Soc. Sci., 5: 61-66.
Hyttia, N. and J. Kola, 2006. Finnish citizen's attitude towards multifunctional agriculture. J. Int. Food Agribus. Manage. Rev., 9: 1-22. http://ageconsearch.umn.edu/bitstream/8203/1/200 51051_Formatted.pdf

James, J.S., 2004. Consumer knowledge and acceptance of agricultural biotechnology vary. J. Calif. Agric., 58: 99-105. http://escholarship.org/uc/item/7km20933\#page-2

Kumar, P., 2007. Resources provision, productivity and contract farming: A case study of Punjab. Proceeding of the ICAR-NCAP and USAID, May 5-6, New Delhi ,India.

Man, N., 2007. The Agricultural Community. 50 Years of Malaysian Agriculture. Malaysian Agriculture: Transformational Issues, Challenges and Direction. UPM, Serdang, Selangor, Malaysia, ISBN: 978967-5026-14-0, pp: 128-144.

Man, N., 2008. Persepsi terhadap pertanian di kalangan belia tani dan keperluan pendidikan pertanian. J. Pembangunan Belia Malaysia, 1: 99-114.

Mann, S. and H. Kogl, 2003. On the acceptance of animal production in rural communities. J. L Use Policy, 20: 243-252. DOI: 10.1016/S02648377(03)00025-5

Mansur, K., M. Tola and R. Ation, 2009. Contract farming system: A tool to transforming rural society in Sabah. MPRA. http://mpra.ub.unimuenchen.de/13271/

Minot, N., 1986. Contract farming and its effect on small farmers in less developed countries. Michigan State University. http://ideas.repec.org/p/ags/midiwp/54740.html

Morrison, P.S., W.E. Murray and D. Ngidang, 2006. Promoting indigenous entrepreneurship through small-scale contract farming: The poultry sector in Sarawak, Malaysia. FAO. http://www.fao.org/ag/ags/contract-farming/agslibrary/detail-fr/fr/item/3797/icode/7/?no_cache=1

Norsida, M., 2007. The Agriculture Community. In: 50 Years of Malaysian Agriculture: Transformational Issues, Challenges and Direction, Arshad, F. et al. (Eds.). UPM Publisher, Serdang, Selangor, ISBN: 978-967-5026-14-0, pp: 128-143.

Osborne, E.W. and J.E. Dyer, 2000. Attitudes of Illinois agriscience students and their parents towards agriculture and agricultural education program. J. Agric. Educ., 41: 50-59.

Shaban, A.A., W. Doppler and H.P. Wolff, 2006. Determinants of farmers acceptance of treated wastewater in irrigated agriculture in the Northern Gaza Strip. Proceeding of the Conference on International Agriculture Research for Development, Oct. 11-13, Tropentag, Germany, pp: 1-1. 
Singh, S., 2005. Contract farming for agricultural development: Review of theory and practice with special reference to India. New Concept Information Systems Pte. Ltd. http://ideas.repec.org/p/ess/wpaper/id246.html

Stobbelaar, D.J., G. Casimir, J. Borghuis, I. Marks and L. Meijer, 2007. Adolescents attitudes towards organic food: A survey of 15 to 16 years old school children. Int. J. Consum. Stud., 31: 349-356. DOI: 10.1111/j.1470-6431.2006.00560.x
Wheeler, S.A., 2008. The barriers to further adoption of organic farming and genetic engineering in Australia: Views of agricultural professionals and their information sources. J. Renew. Agric. Food Syst., 23: 161-170. DOI: $10.1017 / \mathrm{S} 1742170507002128$ 